\title{
Consigning the Twentieth Century to History: Alternative Narratives for the Modern Era
}

\section{Citation}

Maier, Charles S. 2000. Consigning the Twentieth Century to history: Alternative narratives for the modern era. American Historical Review 105(3): 807-831.

\section{Published Version}

http://dx.doi.org/10.2307/2651811

\section{Permanent link}

http://nrs.harvard.edu/urn-3:HUL.InstRepos:3206819

\section{Terms of Use}

This article was downloaded from Harvard University's DASH repository, and is made available under the terms and conditions applicable to Other Posted Material, as set forth at http:// nrs.harvard.edu/urn-3:HUL.InstRepos:dash.current.terms-of-use\#LAA

\section{Share Your Story}

The Harvard community has made this article openly available.

Please share how this access benefits you. Submit a story.

Accessibility 


\title{
Forum Essay \\ Consigning the Twentieth Century to History: Alternative Narratives for the Modern Era
}

\author{
CHARLES S. MAIER
}

How will historians ANALYZE THE CENTURY that has just concluded? What narratives or interpretations will they construct to make sense of the last hundred years? A century of world wars, of political violence, of modernization? Will the twentieth century cohere as a historical epoch? For historians and the reading public alike, centuries provide a ready-made chronological framework for largescale history. Nevertheless, I believe that the idea of twentieth-century history will serve us as a temporal framework only in very selective ways. It may remain as the shorthand designation for what I discuss below as one or another "moral narratives." It will not, though, serve us as well for demarcating economic development or large-scale institutional change, what we can call "structural narratives." 1 These structural narratives, this essay will argue, involve trends that have unfolded in a tempo independent of the twentieth century. What follows is an effort to juxtapose these two chronological perspectives-structural and moral narratives, and of one structural narrative in particular-with their respective claims about historical significance and historical periodization.

The problems that a twentieth-century history presents do not arise just because of ragged beginning and end points, such that 1914 and 1989, rather than 1900 and 2000 , are envisaged as opening and closing the political story, at least of Western history. Neither does the difficulty result from the fact that internal caesuras-whether, above all, the defeat of fascism and the end of the world wars in the case of the European narrative or the achievement of decolonization with respect to the Asian, Middle Eastern, and African history-are so profound that the $1900 \mathrm{~s}$ as a whole retain little "structural" unity. Instead, I would urge, to focus on the "twentieth century" as such obscures one of the most encompassing or fundamental sociopolitical trends of modern world development, namely the emergence, ascendancy, and subsequent crisis of what is best labeled "territoriality." Making the case for the significance of territoriality is a principal objective here. Insofar as the case

1 See Reinhart Koselleck, "Representation, Event and Structure," in Koselleck, Futures Past: On the Semantics of Historical Time, Keith Tribe, trans. (Cambridge, Mass., 1985), 105-15, for the emptiness of natural chronology, the establishment of diachronic structures inherent in the narrative flow of perceived events, and "structures," which are non-narrative concepts designed to make sense of the medium or long-term-and which have no less "reality" than events within a narrative framework (pp. 111-12). 
is persuasive, the landmark dates of the twentieth century become less compelling for periodization.

Territoriality means simply the properties, including power, provided by the control of bordered political space, which until recently at least created the framework for national and often ethnic identity. ${ }^{2}$ Despite our taking it as a given for so long, territoriality has not been a timeless attribute of human societies. It is a historical formation, and its political form was also historical, that is, it has a beginning and an end. But it has not followed the trajectory of the century through time, providing rather the spatially anchored structures for politics and economics that were taken for granted from about 1860 to about 1970 or 1980 but that have since begun to decompose. Hence this article constitutes a plea for historians to envisage a historical era that took shape in the second half of the nineteenth century and, just as important, effectively unraveled in the two to three decades before the century formally ended.

Why privilege territoriality as a key for periodizing modern history? If focusing on processes, why not emphasize industrialization, or the rise of nationalism and nation-states, the great ideological confrontations of Left and Right, whether fascism and communism or democracy and authoritarianism more generally, or just the recourse to mass political violence? If focusing on collective protagonists, why not changing class structure or transformed gender roles? I am not claiming that any one sort of transformation is prior to all the others, although territoriality is

${ }^{2} \mathrm{My}$ interest in the politics of space and territory followed an investigation of "the politics of time" and goes back to the cycle of the SSRC-ACLS Joint Committee on Western Europe in the early 1980s, chaired by Philippe Schmitter, whose ideas on questions of governance and scale helped prod my own. This article is a revised version of my plenary session presentation to the American Historical Association Meeting in January 2000, Chicago; it was also read at the American Academy in Berlin, and a variant on the issue of frontiers and territoriality was presented to the International Security Studies workshop at Yale University, February 2000 . I first developed the concept of territoriality as a key to periodization in a paper presented to the Italian Society for the Study of Contemporary History (SISSCO) in May 1996, published as "Secolo corto o epoca lunga? L'unità storica dell'età industriale e le trasformazioni della territorialità," in '900: I tempi della storia, Claudio Pavone, ed. (Rome, 1997), 29-56. I outlined contrasting moral histories in my lecture to the Mulino association in Bologna in November 1999, since published as "Il Ventesimo secolo è stati peggiore degli altri? Un bilancio storico alla fine del Novecento," Il Mulino 48, no. 386 (November-December 1999): 995-1011. This article is an effort to refine and confront these two interpretive categories. In general, geographers and social theorists rather than historians (exceptions cited below) have tended to thematize the issue. See especially Jean Gottmann, The Significance of Territory (Charlottesville, Va., 1973); Robert David Sack, Human Territoriality: Its Theory and History (Cambridge, 1986); Ivo D. Duchachek, The Territorial Dimension of Politics: Within, Among and Across Nations (Boulder, Colo., 1986); Friedrich Kratochwil, "Of System, Boundaries, and Territoriality," World Politics 39 (1986): 27-52; David Harvey, The Condition of Postmodernity: An Enquiry into the Origins of Cultural Change (Cambridge, Mass., 1989); and John Gerard Ruggie, "Territoriality and Beyond: Problematizing Modernity in International Relations," International Organization 47 (1993): 139-74; John Agnew, "The Territorial Trap: The Geographical Assumptions of International Relations Theory," Review of International Political Economy 1 (1994): 53-80; Peter J. Taylor, "The State as Container: Territoriality in the Modern World System," Progress in Human Geography 18 (1994): 151-62; Bertrand Badie, La fin des territoires: Essai sur le désordre international et sur l'utilité sociale du respect (Paris, 1995); Mathias Albert and Lothar Brock, "Debordering the World of States: New Spaces in International Relations," New Political Science, no. 35 (Spring 1996): 69-106. Immensely stimulating, but less about bounded spaces than the social creation of spatiality, is Henri Lefebvre, The Production of Space, Donald Nicholson-Smith, trans. (Oxford, 1991; French edn. 1974). In the notation that follows, I have attempted to indicate my reliance on work from other disciplines as well as identify direct sources, but, unlike the case for many of the articles in this journal, I have not provided bibliographical orientation for the historical sequences I suggest. These involve vast literatures that I cannot pretend to have read. 
caught up with the others and does offer an encompassing variable. Just as crucial, territoriality appears to be evaporating in many ways before our eyes, a process partially and rather ahistorically captured by the notion of globalization. The contemporary dissolution of a structural order allows researchers to glimpse trends formerly so ubiquitous they had not been perceived as issues for historical. investigation. G. W. Hegel's famous owl of Minerva takes wing at dusk. Territoriality has been so pervasive a principle for organizing societies that only as it has begun to dissolve have social scientists and historians come to fathom its role. Epochs of world history hinge not only on the rise and fall of great powers or the successive struggles among mobilized social groups but on the attributes of political space, whether weakened or strengthened or rescaled into larger or smaller commanding units.

Arguments about periodization remain meaningful only because they represent claims as to what constellations of events should be accorded major significance for defined communities of actors. Periods-whether defined by actual units of time (a decade, a century) or by a figurative span that covers some related events (the Renaissance, Late Antiquity) - stipulate the extension across time of developments that seem to have some relationship to each other and as a group contrast with earlier or later sequences. Historians understand that many designations of periods are descriptive, not causal concepts: the Enlightenment as such never caused skepticism about organized religion or the social benefit of torture. Historical periodization is an effort to interpret more than to explain; that is, to assign a meaning to historical phenomena by relating them either to sequential chains of other events or to webs of relationships, including institutions, social groups of one sort or another, or even mentalités that endure across a significant length of time.

It remains ambiguous whether periodization implies an inherent unity to events, a sort of unavowed Zeitgeist, or, when applied to cultural products, an overarching style. Krzysztof Pomian has written:

Every periodization belongs to the sort of operation that establishes ties between the visible and the visually inaccessible: the invisible, the reconstructible, the observable, or, if one wishes, between the factual and the conceptual. But within that family of operations it has a particular position by virtue of the status it gives to time: to construct a periodization is to admit that the succession of facts or objects is not just a simple appearance, that it reflects something real. The realities inaccessible to view are presupposed as continuous, aligned, separated by zones of rupture that nonetheless leave something that endures, and [they are] arranged in the order of succession, in brief, inscribed in time and endowed each one, with a temporal thickness. ${ }^{3}$

Most Anglo-American historians would probably find this view somewhat mystical. All sorts of potential connections might be discerned among different classes of chronologically bounded events: a persuasive periodization alerts us to select one

\footnotetext{
${ }^{3}$ Krzysztof Pomian, L'ordre du temps (Paris, 1984), 161. The discussion concludes a long section on the concept of historical epochs. Pomian emphasizes the use historians make of concepts of epoch to orient values about the present or the future. I have presented some ideas about periodization in general as "I paradossi del 'prima' e del 'poi': Periodizzazioni e rotture nella storia," Contemporanea 2 (October 1999): 715-22. (English version by e-mail on request.)
} 
set and, just as critical, to overlook the evidence of others. To periodize is to dismiss evidence as much as to gather it.

That is one reason why debates over periodization usually follow a predictable and sometimes dreary course. Historians deploy two sorts of argument. The first type entails a series of claims that a development hitherto taken to mark one era-the renewal of humanistic learning, for example, or the onset of decisive economic transformation, or the emergence of bureaucratic organizations, or the cultural markers of modernity-can be observed in an earlier one and has just been overlooked. Significant developments thus seem to creep backward through time. The counterargument is that the earlier appearances are scattered and do not make enough of a difference to characterize an era until they achieve a certain frequency. At stake is the familiar issue, namely, when do disparate intellectual products, technological innovations, social and national conflicts, and institutional transformations become the shaping forces of public life? Or, as Marxists liked to ask, when do changes in quantity became changes in quality?

Two different questions tend to overlap here: first, the question of when it makes sense to talk of a new historical era (how much change has accumulated?), and second, the question of whether such a new era ordinarily begins with a historical rupture or "saltation," that is, with nonlinear change. As development of the calculus formally demonstrated in mathematics, incremental changes as well as major upheavals can produce large-scale transformations. Nonetheless, perhaps influenced by the radical shifts in world politics during 1989-1990, historians seem more receptive at present to models of sudden transformation. Histoire événementielle no longer refers to events as mere "surface disturbances, crests of foam," atop the longue durée as Fernand Braudel's stratified model suggested; rather, events can be interpreted as themselves constituting or catalyzing "deeper" transitions, which means even profound change can take place suddenly. ${ }^{4}$ To account for these rapid shifts, some historians borrow the idea of "punctuated equilibrium" from paleontology; others have been tempted to cite such mathematical models as René Thom's "catastrophe theory" of the 1970 s, or appeal to partially digested versions of "chaos theory," which stress its doctrine of indeterminacy from initial conditions but not its large-scale effort to establish ranges of predictability. Few historians are qualified to participate in discussions of "dynamical systems theory," which envisages not predictable events but ranges of nonlinear processes. In any case, these mathematical branches have so far offered the historian only analogies and metaphors. ${ }^{5}$ Since

\footnotetext{
${ }^{4}$ Fernand Braudel, The Mediterranean and the Mediterranean World in the Age of Phillip II, Sian Reynolds, ed., vol. 1 (New York, 1975), "Preface to the First Edition," 21. See also Braudel, Ecrits sur l'histoire (Paris, 1969), 75-81, for a more subjective or pragmatic invocation of la longue durée.

${ }^{5}$ For a sample of some of the work under way, see Melanie Mitchell, James P. Crutchfield, and Peter T. Hraber, "Dynamics, Computation, and the "Edge of Chaos': A Re-Examination," and James P. Crutchfield, "Is Anything Ever New? Considering Emergence," both in Complexity: Metaphors, Models, and Realities, George A. Cowan, David Pines, and David Meltzer, eds., Proceedings, Vol. 19, Santa Fe Institute Studies in the Sciences of Complexity (Reading, Mass., 1994), 497-533; for difficulties for social-science application, see the general discussion, "What Are the Important Questions?" 651-60. On catastrophe theory, see the discussion by its advocate, René Thom, Paraboles et catastrophes: Entretiens sur les mathématiques, la science et la philosophie, Giulio Giorello and Simona Morini, eds. (Paris, 1980), 59-113 (which unfortunately yields little for any historian of politics and society). For a positive response to the utility of chaos theory, see Stanley J. Tambiah, Leveling Crowds: Ethnonationalist Conflicts and Collective Violence in South Asia (Berkeley, Calif., 1996), 294-96.
} 
postmodern historiography often contents itself with illumination rather than explanation, such insight may seem an adequate goal. Increasingly, historical works are praised for qualities akin to metaphorical suggestiveness rather than traditional causal analysis. To insist on the latter is sometimes disdained as an old-fashioned vestige of nineteenth-century positivism. ${ }^{6}$

The increasing value placed on the metaphorical capture of historical truth will assure that the twentieth century remains an important historical referent. My argument is not that it cannot serve as a meaningful historical period but that it retains importance for interpretive or moral but not analytical or structural narratives. Centuries have always claimed a canonic status as historical divisions. Given the Latin language inheritance, it was easy to slip from "age" to "century," as did Voltaire, when writing of four great siècles of human cultural and political attainment. ${ }^{7}$ What metaphoric truths, then, are captured by the twentieth century? Both Henry Adams at the beginning of the century and Reinhart Koselleck three-quarters of the way into it claimed that the acceleration of historical time itself was what made contemporary history special: "Our modern concept of history has initially proved itself for the specifically historical determinants of progress and regress, acceleration and delay." 8 But acceleration is not a sufficient criterion for ascribing some epochal quality to the century. Instead, centuries often form the chronological boundaries for what might be called moral narratives. We associate cultural innovation or business cycles with decades (the prosperity of the "twenties"

Popularized presentations appear in James Gleick, Chaos: Making a New Science (New York, 1988); and Mitchell M. Waldrip, Complexity: The Emerging Science at the Edge of Order and Chaos (New York, 1992).

6 Perhaps the best short description of the qualities postmodern history seems to prize is found in Walter Benjamin, "Über den Begriff der Geschichte," in Gesammelte Schriften, 6 vols. in 12 (Frankfurt am Main, 1974-85), 1, 2, pp. 695-98. That fragment stresses history as a retrospective glimpse of cumulative social wreckage. But Benjamin elsewhere allowed for a history that entailed a future politics, as if dreams prefigured action upon awakening: "dialectical thought is the organ of historical awakening." Das Passagen-Werk, Rolf Tiedemann, ed., 2 vols. (Suhrkamp, 1983), 1: 59, and the more sustained reflections, $490-92$. I use the term positivism but in a way similar to what Ian Hacking terms scientific realism in Representing and Intervening: Introductory Topics in the Philosophy of Natural Science (Cambridge, 1983); Hacking admits to a "realism" in connection with imputed scientific constructs such as quarks but suggests that others, such as lines of force, are just constructs-if so, they are the analogs to historical periods. It might be more natural to call such a common-sense approach positivism, but Hacking reserves that for a skepticism about statements concerning entities behind the descriptions (pp. 40-57). The metaphoric quality may be enabling rather than disabling, for metaphor might justifiably appear as the characteristic mode of cognition of twentieth-century social and even natural science. Compare Peter Galison, Image and Logic: A Material Culture of Microphysics (Chicago, 1997), 19-40, and his metaphors of communication, 46-63. I would even argue that metaphor has increasingly become the characteristic mode of scientific cognition (including the social sciences) since the late nineteenth century. But if so, how do we impose any restraints? For a recent example of an extreme recourse to metaphor and illumination, see Roberto Calasso, The Ruin of Kasch, William Weaver and Stephen Sartarelli, trans. (Cambridge, Mass., 1994), 182-83. For extended arguments that metaphor remains central to historical and political representation, see F. R. Ankersmit, History and Tropology: The Rise and Fall of Metaphor (Berkeley, Calif., 1994); and Ankersmit, Aesthetic Politics: Political Philosophy beyond Fact and Value (Stanford, Calif., 1995), chaps. 5-6.

7 Voltaire, Le siècle de Louis XIV, as cited by Pomian, L'ordre du temps, 123-24.

${ }^{8}$ Henry Adams, The Education of Henry Adams (New York, 1931), 489-97, 501; Reinhart Koselleck, "History, Histories, and Formal Structures of Time," in Futures Past, 102. See also "Space of Experience' and 'Horizon of Expectation': Two Historical Categories," 283-84. On the cultural receptivity to such fin-de-siècle reflections as Adams's, see Stephen Kern, The Culture of Time and Space, 1880-1918 (Cambridge, Mass., 1983). 
or the ideological confrontations of the "thirties" or the "sixties," the conformism of the "fifties"), whereas centuries serve for the natural span of moral progress or regression. Most indelibly, the twentieth century has come to symbolize or encapsulate the narratives of moral atrocity that continue to transfix intellectuals and the public alike. For Western intellectuals, the twentieth century does not refer primarily to a strictly chronological unit. Rather, it constitutes a moral epoch, a dark historical passage characterized by ideological conflict, dehumanization, wholesale political killing, unmeasured cruelty to civilians in war, and genocide. Thus the twentieth century remains inscribed, as Isaiah Berlin summarized it, as "the worst century there has ever been."

Given this moral characterization, the historian faces the question of how to relate the period to the epoch, that is, the structural narrative to the moral narrative, the century as a time span in which a complex set of institutional changes take place to the century as an era in the moral history of humanity. Is there any relationship between the narratives of moral atrocity, which presuppose that the twentieth century forms in some sense a coherent if metaphorical epoch (for example, the Century of Auschwitz or of Totalitarianism), and the sociopolitical story that I believe should be based on a different time span? Are the sociopolitical analyses and the moral narratives nonsynchronous?

Most frequently, the major effort to link the two has invoked the concept of "modernity," to which has been attributed an ambiguous impact, suggesting, on the one hand, possibilities of emancipation and, on the other, resources for domination. This now familiar critique represents a prevalent moral narrative, according to which the development of the physical and the social sciences at least facilitates, if it does not specifically drive, projects for dehumanization and genocide. For Max Horkheimer and Theodor Adorno, technological rationality produced the threat of fascism and the manipulative banality of the culture industry; for Michel Foucault, modern knowledge and carceral control increased apace; for Zygmunt Bauman, modernity made possible the Holocaust. ${ }^{10}$

Nonetheless, their ambiguous modernities hardly constituted a rigorous chronological period. There are in fact more determinate linkages between moral and structural narratives, and instead I will attempt to establish a different sort of interplay between time span and moral narrative in the third part of this article. Intellectuals and historians have developed not just one but two or even three narratives of moral atrocity for the twentieth century. While not mutually exclusive, they emanate from different constituencies; and, revealingly, their relative persuasiveness depends on the time periods chosen to make historical sense of the modern era. Their relative persuasiveness and impact depend, in fact, on the rise and fall of territoriality proposed here as an alternative chronology to that of twentieth-

\footnotetext{
${ }^{9}$ Cited by Michael Ignatieff, Isaiah Berlin: A Life (New York, 1998), 301.

${ }^{10}$ Max Horkheimer and Theodor W. Adorno, Dialectic of Enlightenment, John Cumming, trans. (New York, 1972); Michel Foucault, Discipline and Punish: The Birth of the Prison, Alan Sheridan, trans. (New York, 1977); Zygmunt Bauman, Modernity and the Holocaust (Ithaca, N.Y., 1989); and compare Omer Bartov, Murder in Our Midst: The Holocaust, Industrial Killing, and Representation (Oxford, 1996), $67-70$, for the Holocaust as "the culmination ... of a process begun in the late eighteenth century and still continuing." Despite the popularity of the connection, I believe the attribution of the Holocaust to modernity far too diffuse a causal model to advance historical comprehension.
} 
century history. The periodization proposed here for sociopolitical development thus makes sense of the respective claims between these moral narratives. Finally, in way of a brief conclusion, I will suggest that these differing narratives of moral atrocity have different implications for the contemporary epoch-one warns us against ambitious political agendas, while the other cautions us against abandoning politics in our contemporary enthusiasm for the market.

When CITED by historians, centuries are like Procrustes' famous bed: the Greek innkeeper either stretched his guests if they were too short or chopped them down if they were too long for the sleeping accommodations that were offered. By and large, historians of the West have stretched the 1800s into the "long nineteenth century," extending until World War I. Europeanists, at least, have conceived of it as the century marked by industrial development, the triumph of the modern nation-state, the advent of mass democracy (although in this respect, Arno Mayer has certainly dissented with his insistence on the persistence of the power of agrarian elites), the partition of much of what would later come to be called the Third World, and finally by its supreme confidence in economic and moral progress. As a pendant to this "long nineteenth century," finally terminated by World War I, Eric Hobsbawm's concept of a "short twentieth century" starts in 1914 and concludes in 1989. Essentially, Hobsbawm's twentieth century spans the rise and fall of the socialist project, including its Soviet incarnation, justified finally by having helped to rescue, then stabilize, liberal capitalism. ${ }^{11}$

Even if these dates were proposed only to periodize European history, debate would be possible. The trajectory of nationalism and fascism make the years from 1870 or 1890 to 1945 a plausible epoch. Developments in science and art as well as the international crises and the reappearance of revolution might suggest 1905 as the century's curtain raiser. Certainly, Hobsbawm's dates must serve the chronology of African and Asian histories far less well. Historians who have comparative ambitions must ask, are there caesuras and epochs that encompass world historical development? Theorists of capitalism as a transnational economic system, propelling European, American, and non-Western societies through turbulent cycles of social and political upheaval, believe there are, and Giovanni Arrighi has proposed a "long twentieth century" that itself climaxes three hegemonic phases of historic capitalism-Dutch, British, and American-each of which has imposed a different type of economic inequality and increasingly dissolved the prerogatives of sovereign nation-states. ${ }^{12}$

But there is little gained by clinging to either a short or a long twentieth century as the strategic temporal framework. I would propose instead that a coherent epoch

11 Eric Hobsbawm, The Age of Extremes: A History of the World, 1914-1991 (New York, 1994); Arno J. Mayer, The Persistence of the Old Regime: Europe to the Great War (New York, 1981).

12 Giovanni Arrighi, The Long Twentieth Century: Money, Power, and the Origins of Our Times (London, 1994). Arrighi and the theorists he cites (Terence Hopkins, Immanuel Wallerstein, et al.) view hegemony as a continuing form of domination under the international capitalism of the last four centuries. It is questionable, however, whether hegemony in a general sense flows from economic power alone, nor is it clear that international economic systems are always characterized by the presence of a clear hegemon even in the restricted sense used by poltical economists. 
of world development began in the sixth and seventh decades of the nineteenth century-say, for the sake of simplicity around 1860-and that its technological, cultural, and sociopolitical scaffolding began to corrode and fall apart in the late $1960 \mathrm{~s}$, initiating a process of profound transformation that continues today. In a work that has fallen into undeserved oblivion, the historian Robert Binkley took account of this global transition sixty years ago, when he pointed out that political territories or national units had undergone a great crisis of confederal organization, abandoning, in a process of widespread civil wars, their traditional decentralized structures of politics for more administratively and territorially cohesive regimes. ${ }^{13}$ In the United States of the Civil War era, in Meiji Japan, in the German Confederation and the states of Italy, in the emerging halves of the Habsburg empire, in Canada, Mexico, Argentina, Thailand, and elsewhere, national societies were reforged in a rapid and often violent transformation. To varying degrees, depending on prior state capacity, economic advance, exposure to powerful foreigners, and development, these changes, first of all, strengthened central government institutions at the expense of regional or confederal authority; second, required that internal as well as external military capacity be continually mobilized as a resource for governance; third, coopted the new leaders of finance and industry, science, and professional attainment into a ruling cartel alongside the still powerful but no longer supreme representatives of the landed elite; and, fourth, developed an industrial infrastructure based on the technologies of coal and iron as applied to long-distance transportation of goods and people and the mass output of industrial products assembled by a factory labor force. Even where change was less encompassing, significant reform took place: Great Britain reorganized its party system, expanded its suffrage, professionalized its army, and transferred public education from the church to the state. Russia eliminated serfdom and sought to expand limited representative institutions.

Not all regimes dared consistently to combine all these elements. Imperial rulers sought to control a reform process they required for viable governance but that might easily work to undermine their own supremacy: Alexander II of Russia arrested liberalization after it threatened to escape control. The British carried through limited rationalization of their Indian domain after the 1857 Mutiny, enhancing public British control, promising to invite Indian participation, but unable to give power so completely as demanded by the local economic and political entrepreneurs they helped indirectly to encourage. In China, the Qing Restoration may have been a remarkable effort at dynastic recovery, but it endeavored to remain within the limits of Confucian legitimacy. The Ottoman clock towers of the 1870 s remained monuments to a partial and unsatisfactory modernization. These imperial systems contained too many restive subjects to risk fully mobilizing their diverse indigenous energies. Territorial vastness in these cases still remained as much a source of vulnerability as of control.

${ }_{13}^{13}$ Robert C. Binkley, Realism and Nationalism, 1852-1871 (New York, 1935). Recently, Michael Geyer and Charles Bright have highlighted the same period in their discussion, "World History in a Global Age," AHR 100 (October 1995): 1034-60, esp. 1045-47. On nations and spatiality, see Peter J. Taylor and Colin Flint, Political Geography: World-Economy, Nation-State, and Locality, 4th edn. (Harlow, England, 2000); Colin Williams and Anthony Smith, "The National Construction of Social Space," Progress in Human Geography 7 (1983): 502-18. 
Glancing over a longer time frame, it is apparent that several such epochs of territorial rescaling on a global scale have punctuated the early modern and modern eras. Imperial structures have been hard to keep vital, at least without a fundamental contest with entrenched elites, for more than two or three centuries in any case. Between the sixteenth century and mid-seventeenth century, the rather perforated or weakening jurisdictions of the then great empires-Spanish Habsburgs and Ming, Aztec and Inca (the turn of the Ottomans and Mughals came a bit later)-lost ground to new dynasties or to the more cohesively organized territorial states that refined the concept of sovereignty and often firmed up their frontiers with elaborate fortifications. In the second half of the nineteenth century, another era of rescaling took place. Territories were reconfigured, as new political energy and technological resources were applied to the consolidation of what historians describe as nation-states. During the last two or three decades, societies throughout the world have been undergoing a third reconfiguration of territoriality. But in contrast to earlier epochs, what may be at stake is not merely a change in the scale or level of decisive political or economic power, not just a shift, say, from the national to supranational, as in Europe. Rather, territory itself fades in importance as a political or economic resource - a fundamental transformation of institutional life that too close a focus on the 1900 s must obscure, since the key developments in question crystallized as early as the second third of the nineteenth century and effectively unraveled in the two to three decades before the twentieth century formally ended.

Why were so many societies reforged in the decades from 1850 to 1880 ? A simple diffusionist model will not work; countries on different sides of the world underwent the same changes at the same time. To argue that each one was caught up in its own internal or local history is trivially true, but it begs the issue. Any rational observer taking stock of so many similar transformations in individual societies at the same time must reasonably infer that some overarching impulses were at work; the probability of such multiple coincidences is low indeed. Can we establish some common causal pattern? To be sure, the events of the $1860 \mathrm{~s}$ had their own prehistory. Signs of crisis for the respective old regimes were visible frorn the $1820 \mathrm{~s}$ through the $1840 \mathrm{~s}$ : in the West, the inroads of market capitalism, the percolation of French revolutionary values, and-in southeastern Europe or Latin America- of independence movements. While early socialists perceived the transformation wrought by the factory system, the more widespread agitation gripped the countryside with the creation of vast national markets in land as waves of church properties were nationalized by liberal coalitions in Catholic societies, settlement was thrust west and south in the Americas (helping to augment boom-and-bust price cycles in land and cotton), and the south China countryside was wracked by a massive peasant revolt. Under way, in short, was a profound worldwide deterioration of what in Europe was envisaged as the Restoration social equilibrium, so precariously reestablished after 1815 , whose premise (as that of stability elsewhere) had been the maintenance of firm rural hierarchies. In effect, land was escaping the control of its traditional rulers, its value fluctuated wildly, its population was on the move, and the belief systems that had legitimated its unequal distribution had been profoundly challenged. 
But not all crises produce so vigorous and widespread a reorganization of power and economy. Not all such periods of ferment are resolved by masterly programs of reform "from above" such as marked the middle third of the nineteenth century in so many of the world's societies. In effect, most major countries attempted in a patchwork manner the program that was most coherently carried out in Meiji Japan: a renegotiation of social order, including the pacification of a volatile countryside, as newer and older elites overcame their earlier disputes and jointly exploited the new technological resources that enhanced national power and controlled national territory, above all the dramatic inventions that overcame spatial dispersion, such as steam power, the railroad, and the telegraph. Thanks to these technological possibilities, programs of conservative renewal could be achieved by changing the geographical scale of political control. Such a change of scale would serve the organization of social stability-not, as noted, in all sprawling domains where diverse ethnicities aspired to autonomy and technology remained underdeveloped-but in most of the industrial countries through the next century. It would later facilitate the growing assimilation of the new urban masses and working classes.

Historians and political scientists have tended to take for granted until recently that common to all the successful national reorganizations was an enhanced concept of territory, defined here as a bounded geographical space that provides a basis for material resources, political power, and common allegiance. "Territoriality for humans," one of its theorists summarized a decade and a half ago, "is a powerful geographic strategy to control people and things by controlling area." 14 Territory is not just a background factor in history; it assures a stable sense of community only when "identity space"-the unit that provides the geography of allegiance-is congruent with "decision space" - the turf that seems to assure physical, economic, and cultural security. To emphasize the historical significance of territory is not a plea to return to geopolitics. Advocates of geopolitics in the early twentieth century argued that territoriality was an immutable variable for deciding mastery of a world whose nations were locked in perpetual struggle. In fact, these doctrines were themselves a product of the intensification of territoriality; the diagnosis was part of the symptomology, and it makes little sense to redeploy geopolitical ideas when the relationship of geographic space to identity and to security is in question, as it is today. ${ }^{15}$

As bounded space, territory involves two components: the frontier at the edge and the lands within. Historians have traditionally focused on the role of boundaries, and contemporary scholars, now including literary critics and anthropologists, have emphasized their role for the Roman Empire or in the context of the post-Westphalian, seventeenth-century state system. The religious and state rivalries of seventeenth-century Europe, as well as the resources claimed by the

${ }^{14}$ Sack, Human Territoriality, 21, 32.

${ }^{15}$ For some recent discussions of geopolitics and its contemporary applications, see George J. Demko and William B. Wood, eds., Reordering the World: Geopolitical Perspectives on the 21st Century (Boulder, Colo., 1994); Taylor and Flint, Political Geography, 49-104; and the diverse articles in Journal of Strategic Studies 22 (June-September 1999). For a useful guide to the diverse applications of geographical studies, consult Ian Douglas, Richard Huggett, and Mike Robinson, eds., Companion Encyclopedia of Geography: The Environment and Humankind (London, 1996). 
so-called military revolution, secured the principle of sovereignty and renewed the preoccupation with fortified frontiers that had marked antiquity; indeed, one French historian refers to "the invention of the frontier" to characterize the epoch that ran from Jean Bodin to Sébastien Vauban. The seventeenth and eighteenth centuries comprise the great epoch of enclosure: enclosure of common lands within the villages of Britain and western Europe, enclosure of state borders. As Ewan Anderson has summarized, with the Peace of Westphalia, "it was acknowledged that boundaries drawn around territory circumscribed a single political and legal unit over which the state had sovereignty. The idea of zonal frontiers between core areas of control was rejected and from then, individuals owed allegiance to a specific territory which linked them to sovereign control." 16 Early modern history in the West was, in effect, the history of frontiers and the resources needed to establish them, nor did this preoccupation really fade until very recently. Western (and not only Western) statesmen and publics of the late nineteenth century believed that they must reinforce the frontiers anew. ${ }^{17}$ Something there was that must have loved a wall ... For not only geographical frontiers: social and class upheaval at home as well as renewed international competition compelled an obsession with social enclosures of all sorts: the boundaries that separated nation from nation, urban from rural, and the zones within cities, the conceptual frontiers that divided church from state, public from private, household from work, alleged male from reputed female roles-social and political order was conceivable only through spatial partition.

Decisively renewed in the nineteenth century, as new nations were consolidated and new boundaries created in war, the fixation with frontiers lasted until very recently. Europeans extended it outward from their own states, refitted with new borders in the $1860 \mathrm{~s}$ and $1870 \mathrm{~s}$ to the large areas they penetrated in Asia and Africa. Overseas empires became increasingly seen not as a network of shipping rights and supply stations, nor just of extraterritorial enclaves and zones of coastal penetration. Preferably, for the invigorated and industrialized Europeans of the late nineteenth century, overseas jurisdictions would be transformed into cloned territories offshore that must themselves be clearly bounded. As one of the greatest celebrants of this sort of empire, Lord Curzon could still announce as of 1907, "frontiers are indeed the razor's edge on which are suspended the modern issues of war and peace, of life or death to nations." Indeed, he might have repeated the judgment through $1990 .{ }^{18}$

16 Ewan W. Anderson, "Geopolitics: International Boundaries as Fighting Places," Journal of Strategic Studies 22 (June-September 1999): 127. On frontiers in the seventeenth century, see also Peter Sahlins, Boundaries: The Making of France and Spain in the Pyrenees (Berkeley, Calif., 1989); and Michel Foucher, L'invention des frontières (Paris, 1986).

17 See Peter C. Perdue, "Boundaries, Maps, and Movement: Chinese, Russian, and Mongolian Empires in Early Modern Central Eurasia," International History Review 20 (June 1998): 263-86; and-emphasizing the nineteenth rather than the eighteenth century-Charles P. Giersch, Jr., "Imperial Geography, Local History, and Changing Notions of Territory in Modern China," presented at the Yale University International Security Studies Conference on Geography and International History, February 2000.

18 George Lord Curzon of Kedleston, Frontiers: The Romanes Lecture of 1907 (1908; rpt. edn., Westport, Conn., 1976); cited in Anderson, "Geopolitics," 128. On boundaries, see also J. R. V. Prescott, Political Frontiers and Boundaries (London, 1987); Stephen B. Jones, "Boundary Concepts in the Setting of Place and Time," and Ladis K. D. Kristof, "The Nature of Frontiers and Boundaries," 
NONETHELESS, TO UNDERSTAND THE MODERN CONCEPT OF TERRITORY, and thus of state and even nation, indeed of international order, borders are not enough. Beginning with the programs of enlightened monarchs and then profoundly transformed by the resources of industrialization, a new quality of territoriality will emerge as important. It is a product of what is happening within the borders. The area within will no longer be construed as a passive enclosure to be policed and kept orderly; it will be a source of resources, livelihood, output, and energy. Territory is envisaged not just as an acquisition or as a security buffer but as a decisive means of power and rule. ${ }^{19}$ What were the assets of territoriality? First, simply physical extent; and, if limited by nature or neighbors, by the end of the century territorial ambitions encompassed overseas empires, while geopolitical theorists divided over whether maritime or landed extension offered more power. Population was obviously a resource; so, too, was economic development, a concept developed by early mercantilist theorists, then carried forward from the late eighteenth century by writers as diverse as Alexander Hamilton and Friedrich List, and thereafter discussed in close association with strategic capacity by such commentators as Ivan Bloch. ${ }^{20}$

For a sense of what is at stake, it is revealing to consider the testimony of physical science. Every historical era tends to keep its political institutions and its images of the physical world in some sort of congruence. Both testify, I believe, to an overarching spatial imagination that will persist for decades, or even centuries, but can change rapidly when it finally gives way. In 1861 and 1862, while Abraham Lincoln's inexperienced armies found themselves mauled as they sought to reestablish control over just a few northern reaches of insurrectionary Virginia, and again in 1864 as these now more seasoned soldiers discovered how costly it was to attack even an exhausted enemy in swamps and trenches, James Clerk Maxwell tried to explain what he (and earlier Michael Faraday) meant by "physical lines of force." Prior to Faraday, electrical, magnetic, and gravitational force presupposed action of one body over another at a distance. But Faraday's experiments as elaborated by Maxwell's field theory implied that space itself was potentially energized-that every point in space could be assigned a quantity and direction of force, which might leave its traces in the iron filings scattered on a paper above a magnet. As the armature of a generator rotated, it bent and broke through such

both in Annals of the Association of American Geographers 49 (1959): 241-55 and 269-82. For Antiquity, see Derek Williams, The Reach of Rome: A History of the Roman Imperial Frontier, 1st-5th Centuries AD (London, 1996).

${ }_{19}$ The prerequisite for utilization of territorial resources was mapping. The history of mapping has by now become a significant scholarly specialty, paradigmatic for the creation of orderly rule and empire. See Roger J. P. Kain and Elizabeth Baigent, The Cadastral Map in the Service of the State: A History of Property Mapping (Chicago, 1992). For an exemplary study, see Matthew H. Edney, Mapping an Empire: The Geographical Construction of British India, 1765-1843 (Chicago, 1990); also Tongchai Winichakul, Siam Mapped: A History of the Geo-Body of a Nation (Honolulu, 1994); Alan K. Henrikson, "The Power and Politics of Maps," in Demko and Wood, Reordering the World, 49-70; and compare James C. Scott, Seeing Like a State: How Certain Schemes to Improve the Human Condition Have Failed (New Haven, Conn., 1998), 87: "All the state simplifications that we have examined have the character of maps."

${ }^{20}$ See Jean de Bloch (Ivan Blioch), The Future of War in Its Technical, Economic and Political Relations (Boston, 1899), an English abridgement of the six-volume Russian edition, for a discussion of the aggregate cost of general war and the weakness of the Russian resource base in particular. 
lines of force. In effect, Maxwell explained, empty space could be filled with potential and kinetic energy; a set of differential equations could establish the total of these energies, attributed to electrical and magnetic fields, for every point. ${ }^{21}$ Maxwell's laws, moreover, were represented by vectors; that is, they had a direction. So, too, territories had a center, the national or regional capital from which political and economic energy radiated outward and products flowed inward from a "tributary" countryside. (In contrast, today's metropolises are wired to each other, not their national hinterland, and conceived of as suspended in a world network of capital and labor.) $)^{22}$

I cite Maxwell to suggest that at the very moments he was writing, an analogous conception of energized space was transforming the organization of global territoriality. The lines of force posited in the laboratory were matched by the lines of force knitting together the new world. In the same decade that Maxwell puzzled over the physical interpretation of his differential equations, the coalitions of modernity strung telegraph lines and later oceanic cables and telephone lines and crisscrossed their territories with railroad lines and the seas between them with steamship lines. Maritime routes and rail lines, the French geographer Paul Vidal de la Blache would write by 1921, formed a global network: "By virtue of their regions' intimate penetration, of this universal contact that so few can still escape, everywhere there is cargo to collect, transactions to carry out, needs to satisfy. Thus a new activism arises and animates every part of the globe." 23 But the new lines of force divided as well as connected. No culture obsessed more about borders than the one taking shape by the mid-nineteenth century, insisting on national, racial, gender, and class lines. The modern world was gripped by the episteme of separation. When the boundaries were transgressed or could not be stabilized, social orders degenerated. Liberals and revolutionaries as well as expansionists shared the conviction that tribal peoples lacking territorial structures must succumb to modern states. In the most architectonically conceived artwork of the age, when the boundaries that separated brother from sister, gods from men, and the values of gold from those of blood were transgressed, Valhalla itself perished.

Even as a new class of political leaders believed they must establish frontiers anew, they also emphasized that national power and efficiency rested on the saturation of space inside the frontier. National space was to be charged with "energy" throughout, like the ether. "As sure as a fact yields only to fact," August Ludwig von Rochau argued, "so it is sure that neither a principle nor an idea nor an agreement will unite the dispersed German energies, but only a superior energy which swallows up the others." A. E. Schäffle proposed that national economic

21 Jed Z. Buchwald, From Maxwell to Microphysics: Aspects of Electromagnetic Theory in the Last Quarter of the Nineteenth Century (Chicago, 1985), 22 and following; L. Pearce Williams, The Origins of Field Theory (Ithaca, N.Y, 1980), 121-37, which dates early decisive statements to late 1855 and early 1856.

${ }_{22}$ Contrast the nineteenth-century vision of "tributary" cities-spatially centered in a surrounding land mass (as theorized in 1826 by Johann Heinrich von Thünen's isolated state)-in William Cronon, Nature's Metropolis: Chicago and the Great West (New York, 1991), 43-54, with Saskia Sassen, The Global City: New York, London, Tokyo (Princeton, N.J., 1991), 168-91. Is Cronon's peroration about the interdependence of city and country (pp. 384-85) still relevant for the postmodern urban order?

${ }_{23}$ Paul Vidal de la Blache, Principes de géographie humaine (Paris 1995), 268. 
energies must flow freely throughout a territory. ${ }^{24}$ Territory would be pervaded with prefectures and subprefectures, post offices, railroads and infrastructure, masscirculation newspapers, telegraphic communication, and the possibilities of electrical power in general. Territorial consciousness now meant that no point inside the frontiers could be left devoid of the state's control, just as no point within a field was devoid of physical force. Administrative energy in the form of primary schools, prefectures, and railroads would pervade and "fill" the nation's space.

The telegraph, steamboats, and the railroad meant that far more points within the state's territory could be supervised by administrators, opened for economic exploitation, mobilized for national purposes. In Hungary, the liberal nationalist István Széchenyi pleaded for railroad development; in Italy, Camillo Cavour wrote that the railroad would especially assist the backward countries: "For such nations railways will be more than a means of self-enrichment; they will be a powerful weapon with the help of which they will succeed in triumphing over the retarding forces that keep them in a baneful state of industrial and political infancy." The railroad in the judgment of Carlo Cattaneo would "rapidly correct the evils of history and geography." ${ }^{25}$ Mastery of its techniques allowed the movement of troops on which national power politics rested, as the Northern victories in the American Civil War or the Prussian humiliation of France demonstrated. At the end of the 1860s, Americans had traversed the North American continent with a rail link; control of the new railroads in the American South helped unite the post-Civil War ruling elites. The Canadian Pacific line was driven to the Pacific during the 1880 s, in effect extending the Dominion westward along its dorsal spine. As the Left secured control of the French republic in the same decade, it carried through two major projects: Jules Ferry's secularization of primary education and Charles-Louis Freycinet's national railway web, radiating outward from Paris to modernize the interior of the country so that the national domain might truly be integrated. With the railroads went roads, telegraphic service, commerce, use of the postal service, or as one French commentator quoted: "the railroad-infusion of life."

Everywhere, the material results were impressive. Railroad lines tended to quadruple in the advanced states across the middle three decades of the nineteenth century. The United States went from 6.3 kilometers of track per 1,000 square kilometers in 1860 to 34 in 1890 to 84 in 1920; Britain's tracks had already jumped from 7.6 in 1840 to 46 in 1860 to 89.6 to 134; France from 17 in 1860 to 62 to $70 .{ }^{27}$ Finally, by the end of the century, Count Sergei Witte had engaged Russian energies on the huge Trans-Siberian project. The railroad was the worldwide foundation of economic development, peopling hitherto remote areas, providing the transport infrastructure for commerce, creating a new demand for iron and steel manufacturers and machinists, beckoning with a representation of moral and

\footnotetext{
24 See Theodore S. Hamerow, The Social Foundations of German Unification, 1858-187I (Princeton. N.J., 1969), for German sources.

${ }_{25}$ Cavour's memo on railroads cited by Mack Walker, Plombières: Secret Diplomacy and the Rebirth of Italy (New York, 1968), 47; Cattaneo cited by Raffaele Romanelli, L'Italia liberale (1861-1900) (Bologna, 1979), 69.

${ }^{26}$ Citation from Ardouin-Dumazet, Voyage en France, in Eugen Weber, Peasants into Frenchmen: The Modernization of Rural France, 1870-1914 (Stanford, Calif., 1976), 209.

${ }_{27}$ Peter J. Hugill, World Trade since 1431: Geography, Technology, and Capitalism (Baltimore, 1993), 174.
} 
political progress, supplying a tangible image of energy radiating through the national space, interlacing the national territory with specimens of the lines that were demarcating private and public, national and transnational spheres. British geopolitician Halford Mackinder, who celebrated the strategic resources of the vast heartland of "Eurasia"-an imagined spatial identity if ever there were one-insisted that the mobilization of territory depended on the railroads: "Nowhere can they have such effect as in the closed heartland of Euro-Asia."28

Railroads were not the only means for saturating space. Anthony Giddens rightly links them with the enhanced resources of administrative power more generally (although his account of a continuous development from improved eighteenthcentury transportation to modern electronic information storage elides the critical discontinuities of the mid-nineteenth century and late twentieth). ${ }^{29}$ Government bureaucracies grew far more massive-perhaps sextupling in France during the nineteenth century-although many officials were just the employees of such state enterprises as railroads or gas works. ${ }^{30}$ Centrality, Henri Lefebvre writes, is the critical thrust of bourgeois society. In the nineteenth and twentieth centuries,

centrality aspires to be total. It thus lays claim, implicitly or explicitly, to a superior political rationality (a state or "urban" rationality). It falls to the agents of the technostructure-to the planners-to provide the justification for this claim ... Despite countervailing forces, some subversive, some tolerable-and tolerated on various grounds (liberalization, flexibility, etc.) - the centre continues effectively to concentrate wealth, means of action, knowledge, formation and "culture." In short, everything ... Space is marked out, explored, discovered and rediscovered on a colossal scale. Its potential for being occupied, filled, peopled and transformed from top to bottom is continually on the increase. ${ }^{31}$

Reflecting on the end of the century, Henry Adams was preoccupied by force and power: "the amount of force controlled by society had enormously increased." although he could neither exert it nor explain it. ${ }^{32}$

Consider more generally the industrial technology of the century from the $1860 \mathrm{~s}$ to the 1960s. First, it is designed to move physical objects. It transports masses of people by railroad and ship, then by plane and jet. It digs huge amounts of earth, as in Panama, or piles up vast amounts of water behind large concrete barriers. Size counts. The great expositions of the era celebrate the massive machines that become ever huger: the steam engines at the Centennial Exposition of 1876 would seem small next to the forty-foot turbine that led to Henry Adams's epiphany at the Paris Exhibition of $1900 . .^{33}$ Second, this economy is designed to produce vast

${ }^{28}$ See Geoffrey Sloan, "Sir Halford J. Mackinder: The Heartland Theory Then and Now," Journal of Strategic Studies 22 (June-September 1999): 15-38, esp. 21.

${ }^{29}$ Anthony Giddens, The Nation-State and Violence (Cambridge, 1985), 172-97. See also Michael Mann, The Sources of Social Power, Vol. 2: The Rise of Classes and Nation-States, 1760-1914 (Cambridge, 1993). Both efforts suffer, I think, from over-determination in their respective ambitions to account for the totality of modern European development. For a related effort that remains more rooted in national and period specificity, see Hans-Ulrich Wehler, Deutsche Gesellschaftsgeschichte, 4 vols. (Munich, 1987-).

${ }^{30}$ Eugene N. Anderson and Pauline R. Anderson, Political Institutions and Social Change in Continental Europe in the Nineteenth Century (Berkeley, Calif., 1967), 167.

31 Lefebvre, Production of Space, 332, 334.

32 Adams, Education of Henry Adams, 388-89.

${ }_{33}$ Adams, Education of Henry Adams, 380-81. His mentor Langley was preoccupied by the new form 
numbers of objects, relatively undifferentiated (any color so long as it's black, as Henry Ford said of the Model T). It brings workers by the hundreds to machines and subjects them to their discipline. An industry's efficacy is deemed proportional to its size. Control emanates from the center, and, as Frederick W. Taylor argued, firms should separate the control and planning centers of the enterprise and the unquestioning physical execution of labor. The relationship across space is clearly hierarchical. The headquarters of an enterprise or of government are in the capital; the other branches are subsidiaries. Authority flows "outward" or "down"; output moves "up" from the mine or factory or "in" from abroad. Although firms plant branches abroad and aspire to international activity, they are clearly rooted in a home country, and their domestic business is protected by national tariffs and other legislative measures. The nations of the West remain enchanted with this model through the $1950 \mathrm{~s}$, and Communist economic planners cling to it until the 1970 s and 1980 s. $^{34}$ Between the wars, governments and electrical industry executives coordinate grids designed to provide adequate power over their national territories. Hydroelectric projects are celebrated for mastering an unruly and wasted landscape, not contested for environmental degradation. This paradigm of industrial output, so wedded to territorial development, triumphs with the prodigious feats of German, American, and Soviet production for World War II, and in the next decade captures the imagination of planners and the public with the concept of the integrated steel mill, an installation critical for Jean Monnet's plans for modernizing postwar France, for the Thyssen firm's ambitions to rebuild their fortunes in postwar Germany, for the Italian technocrats working with the para-state agencies for industrial reconstruction, for planners in India and the emerging postcolonial world-all hypnotized by the vision of molten metal moving from crushed ore at one end of the furnaces and extruded at the other end in bars, wires, and sheets.

I cite these concepts-more precisely, motivating images-because they proved fundamental to the collective organization of economic resources and political power for the hundred years or more extending from the $1860 \mathrm{~s}$ to the $1970 \mathrm{~s}$. The era of economic nationalism and protective tariffs starting in the $1870 \mathrm{~s}$, of the subsequent drive to annex overseas territory, of the formation of long-term alliances during peacetime and the ratcheting up of the arms race that preceded the First World War, of the ideological polarization between a Marxian Left and a

of force recently observed, radioactivity, which was to have a future in the twentieth century. The historian "turned at last to the sequence of force; and thus it happened that, after ten years' pursuit, he found himself lying in the Gallery of Machines at the Great Exposition of 1900, his historical neck broken by the sudden irruption of forces totally new" (p. 382).

${ }_{34}$ Alfred D. Chandler, Jr., is the preeminent historian of the rise of the multidivisional corporation, which he sees as the "central institution in managerial capitalism," and traces originally to the organizational challenges presented by extensive territory and rail and telegraphic communication. See Chandler, Strategy and Structure: Chapters in the History of Industrial Enterprise (Cambridge, Mass., 1962); and The Visible Hand: The Managerial Revolution in American Business (Cambridge, Mass., 1977); and three decades later, after Chandler became familiar with German enterprise, Scale and Scope: The Dynamics of Industrial Capitalism (Cambridge, Mass., 1990), esp. 53-89, for the geographical incentives to enlarge firm size. For the argument that such a trajectory of development was contingent and hardly inevitable, see Michael J. Piore and Charles F. Sabel, The Second Industrial Divide: Possibilities for Prosperity (New York, 1984); and Charles F. Sabel and Jonathan Zeitlin, "Historical Alternatives to Mass Production: Politics, Markets, and Technology in Nineteenth-Century Industrialization," Past and Present 108 (1985): 133-76. 
militarist Right, thereafter between communism and fascism, and finally between Soviet power and the Atlantic alliance, all represented stages of historical development within this long era of territoriality. Marxist ideology envisaged a transnational alliance of the proletariat but never divorced the implantation of socialism from the control of territory. Common to all the transformations of politics and permutations of states from the $1860 \mathrm{~s}$ through the $1980 \mathrm{~s}$ - the struggles for hegemony over Europe and in the Pacific, the encompassing ideological confrontations of the first three quarters of the twentieth century, which enlisted so many fervent adherents on different sides, the efforts to restructure international relations by the League of Nations or the United Nations-hence persisting across the admittedly fundamental divides of 1914 and 1945 , the territorial premise of collective life remained fundamental: namely, that a nation's "identity space" was coterminous with "decision space," that the territories to which ordinary men and women tended to ascribe their most meaningful public loyalties (superseding competing supranational religious or social class affiliations) also provided the locus of resources for assuring their physical and economic security.

But the once-reassuring congruence between identity space and decision space has weakened. Bounded space no longer appears a decisive resource; it is a problematic basis for collective political security and increasingly irrelevant to economic activity. When and why did the territorial imperative loosen its grip? The frameworks for political and economic coordination created in the $1860 \mathrm{~s}$ began to dissolve in the late $1960 \mathrm{~s}$ and continued to do so in the capitalist democracies through the decade of the 1970 s and then in the state socialist bloc during the 1980 s-a transitional quarter-century that will, I believe, be apprehended as one of the axial crises of the modern era, as the territorial order became caught up in a process that social scientists endeavored to grasp then as "interdependence" and more recently as "globalization." 35 The processes that undermined the earlier epoch of territoriality were marked by a succession of worldwide difficulties: the weakening of the hierarchical collective discipline that both sides in the Cold War had successfully invoked for the sake of postwar reconstruction and their mutual rivalry; the reappearance of distributive social conflicts and the breakdown of relatively easy collaborative industrial relations in the capitalist democracies; the United States involvement in the Vietnam War and the protests it unleashed; likewise the American unwillingness to continue upholding the international monetary regime it had financed since World War II, usually associated with Bretton Woods; the emergence of new economic contenders, whether through industrialization or the exploitation of their hold on world oil supplies, in Europe

\footnotetext{
35 For a sampler of the more effusive efforts to describe the impact of globalization on international order, see Gearóid O Tuathai, "Postmodern Geopolitics? The Modern Geopolitical Imagination and Beyond," and Timothy W. Luke, "Running Flat Out on the Road Ahead: Nationality, Sovereignty, and Teritoriality in the World of the Information Superhighway," both in O Tuathail and Simon Dalby, Rethinking Geopolitics (London, 1998), 16-38 and 274-94; also such basic statements as Arjun Appadurai, Modernity at Large: Cultural Dimensions of Globalization (Minneapolis, 1996); Manuel Castels, The Rise of the Information Society (Oxford, 1996); Benjamin Barber, Jihad vs. McWorld: How Globalism and Tribalism Are Reshaping the World (New York, 1996); Lee Boon-Thong and Tengku Shamsul Bahrin, eds., Vanishing Borders: The New International Order of the 21st Century (Aldershot, 1998). For a lurid survey from the geographers' point of view, see R. J. Johnston and Peter J. Taylor, eds., $A$ World in Crisis? 2d edn. (Oxford, 1989).
} 
and the Americas; and, shortly thereafter, the emergence of militant social movements among students, women, and nuclear protesters. The gradual renunciation of conscripted military forces, whether formally or through widespread forms of alternate service, dissolved one of the key institutions by which the defense of identity space was built into the life cycle of male citizens.

Finally, the clamorous collapse of state socialism and planned economies during the $1980 \mathrm{~s}$ can be seen as the most spectacular political consequence of the weakening of territorial politics. The state socialist regimes, after all, had committed themselves to controlling politics, economics, and ideology on the basis of territory and frontiers (most tangibly in East Germany). They were also most heavily invested in the aging processes of heavy industry that had characterized the territorial era. They were among the most faithful to the idea of the individual as a long-term producer durably rooted in a continuing workplace and most resistant to his or her decomposition into a virtual wardrobe of multiple roles. ${ }^{36}$

For, just as a qualitative change of technological possibilities for mastering space and its extension had facilitated the political transformations of the century after 1860 , so the very technological transformations of the last thirty years have tended to make physical space a less relevant resource. The age of coal and iron, and then, too, of hydrocarbon chemistry, of oil and electricity, of aluminum and copper as well as steel-all still epitomized as late as the $1950 \mathrm{~s}$ and $1960 \mathrm{~s}$ by the giant integrated steel mill-was overlaid in fact, and in the public imagination, by the technologies of semiconductors, computers, and data transmission, with a new accepted basis for the creation of private wealth. The concept of hierarchically organized Fordist production based on a national territory was supplanted by the imagery, if not always the reality, of globally coordinated networks of information, mobile capital, and migratory labor. The result has been to transform the major political division of our times into one that separates those who envisage their future prospects based on non-territorial markets or exchange of ideas from those who insist that territoriality can be reinvigorated once again as the basis for economic and political security-whether by means of provincial regionalism, or supranational organization, or by harsher measures of ethnic homogeneity. Of course, there are sites of fierce territorial conflict-Kosovo, northern Sri Lankawhere ethnic groups still insist on political hegemony over their province or on subordination of their rivals' sacred sites. But the contenders aspire to a status they have not hitherto enjoyed and which they understand usually would be viable only if cosseted in a larger framework that would provide economic assistance.

The question that remains open is whether territory loses its institutional role in general or whether we are just in one of the eras of rescaling territorial resources, as in the transition from Habsburg to French power, or Dutch to British commercial

\footnotetext{
${ }^{36}$ Sack, Human Territoriality, 5. It is true that the Marxist Left sought to challenge the premises of territoriality and appeal to a revolutionary internationalism. In fact, however, Communists achieved power only by accepting the premises of territorial power and development and building socialism within individual countries or by virtue of a new sort of imperial organization. Social Democrats emerged from their interwar defeats convinced that the nation-state offered an appropriate fulcrum for democratic emancipation. They benefited from the fact that even in the greater part of the world where Communist ideology did not prevail, the social basis of the nation-state had to be enlarged, such that by the 1940 s representatives of the industrial working class were coopted into the power-sharing arrangements from which they had been largely excluded before.
} 
strategies in the late seventeenth century, or from the province and the land to the national state and the metropolis after 1860 . Perhaps territory will prove effective on the scale of the European Union or NAFTA. But while these have territorial designations, decisive resources will not be those of space but of networks and interaction, regardless of the area over which they take place. In this respect, they are akin to the organization of the great imperial networks that preceded the emergence of Westphalian sovereignty and territoriality. An argument can be made either way, just as it is possible to maintain that states can still protect their populations against the harsh effects of globalization. ${ }^{37}$

Even so, the transformations must be profound. The fundamental transitions historians associate with modern history were based on the consolidation of a territoriality that cannot continue in the form familiar to those who took part in public life before 1970. The particular hundred-year span familiar to those who are at least middle aged took shape deep in the $1800 \mathrm{~s}$ and began to decompose a generation ago. "The present epoch," Michel Foucault wrote in 1967, "will perhaps be above all the epoch of space. We are in the epoch of simultaneity; we are in the epoch of juxtaposition, the epoch of the near and far, of the side-by-side, of the dispersed. We are at a moment, I believe, when our experience of the world is less that of a long life developing through time than that of a network that connects points and intersections with its own skein." 38 Sometime between the mid-1960s and the end of the 1980s, beset by doubts and uncertainty about even the viability of democracy and capitalism, we lived through our own fin de siècle.

The TWENTIETH CENTURY, as I proposed at the outset, will remain with us nonetheless, if only as an epoch of moral history, a chronological framework for moral narratives. Admittedly, the concept of moral narrative needs some exposition, if not justification. It is to be sought less in the practice of professional history than in the orientation that intellectuals and commentators expect from history. In this sense, most of them remain Crocean to the core, turning to history as a sort of liberation or exit strategy from the past: "We are products of the past, and we live immersed in the past that presses on us from all sides. How can we move on to a new life, how can we act anew without exiting from the past and getting beyond it? ... There is only one way out, that of thought, which doesn't rupture the relationship with the past but rises above it through ideas and converts it into consciousness. It is necessary to look the past in the face and without metaphysics reduce it to a mental problem or resolve it into a truth statement that will serve as

37 For this argument, see Robert Boyer and Daniel Drache, eds., States against Markets: The Limits of Globalization (London, 1996). See the claim, too, that it is wealthy and strong states that have pressed globalization forward as part of the logic of center-periphery territorialization, in Jean-Michel Hoerner, Géopolitique des territoires: De l'espace approprié à la suprématie des états-nations (Perpignan, 1986), 217-52. The issue, however, is not, as so often claimed, whether states must decline in age of globalization. No such claim is made here. The question is to what degree political jurisdictions can use the resources of territoriality to assure economic security-and that cannot be answered either by counting states or citing their legislative competences.

38 Michel Foucault, "Of Other Spaces," Jay Miskowiec, trans., in Diacritics (Spring 1986): 22, cited by Edward S. Casey, The Fate of Place: A Philosophical History (Berkeley, Calif., 1998), 298. 
the intellectual premise for new action and new life." 39 Despite the antique ring to this program, probably most narrative constructions still represent this sort of endeavor, and the century becomes the chosen temporal unit for such a moral reflection. Whereas the nineteenth century served as the tablet on which historians of the time, and those of our own era, inscribed stories of progress, the twentieth-century story emphasizes narratives of moral atrocity or moral struggle.

In fact, there are at least two divisions of the dominant narratives of moral atrocity, perhaps three, if we count Left and Right variants of the Western or Eurocentric story as separate. The Western narrative, retold by historians and philosophers, museum curators, film producers, and legal experts, focuses on the Holocaust and/or Stalinist Communist political killing as the culminating historical experience of the century, sometimes stressing their differences and sometimes their kinship under the rubric of totalitarian terror. Regardless of how one judges the issue of similarity and distinctiveness, the insistence on connecting these episodes-to argue that the Communist massacres whether in Russia, China, or Cambodia were as horrendous as the Nazi exterminations-usually reflects a belated reckoning with left-wing terror, that is, within the context of what François Furet almost called "the passing of an illusion." 40 As a result, most ink has been spilled on the respective ideological sources, the political intentionality, the categories targeted, and even the body count of these horrendous episodes.

But to many observers from outside the Atlantic world, such a debate seems parochial. Their moral-atrocity narrative maintains that the domination of the West over the massive societies of what once could be called the Third World established the preeminent historical scaffolding of the century. And even as they often focus on the episodes in which formal colonial rule was contested and gave way, their metanarrative continues to emphasize the abiding economic discrepancies between core and periphery, between developed and less developed societies, as its continuing legacy. Likewise, the endemic warfare in Asia and Africa since 1945 and much of the violence in Latin America or the Middle East are also interpreted as legacies of imperial rule or neo-colonial domination. There is no simple agreement within this story: a new generation of researchers stresses the scope for agency on the part of the colonized and exploited and, in fact, the way in which the Europeans' dominion abroad defined hierarchies at home. Still, in this perspective, imperial

\footnotetext{
39 Benedetto Croce, La storia come pensiero e come azione (Bari, 1969), 33-34.

${ }^{40}$ François Furet, Le passé d'une illusion: Essai sur l'idée communiste au XX $X^{e}$ siècle (Paris, 1995), where the author admits (p. 15) that the illusion was also part of his own past, which, however, he refuses to repudiate. For a similar recent assessment, compare Robert Conquest, Reflections on a Ravaged Century (New York, 2000). For the political passions aroused by the historical comparison of Nazi and Communist crimes, see the French controversy over Stéphane Courtois, et al., eds., Le livre noir du communisme: Crimes, terreur, répression (Paris, 1997), which divided its very contributors. It is also indicative of shifting political orientations that Horst Möller, the director of the prestigious Munich Institut für Zeitgeschichte, a leading research center whose original agenda was confronting the Germans' own Nazi past, should publish a collection of debates about the "red Holocaust," Der rote Holocaust und die Deutschen: Die Debatte um das "Schwarzbuch des Kommunismus" (Munich, 1999). For a recent work that implicitly contests these views and separates the terror of civil war (and aggravated by foreign war) from the administered bloodshed of the Great Purges, see Arno J. Mayer, The Furies: Violence and Terror in the French and Russian Revolutions (Princeton, N.J,, 2000). Still the critical starting point for reflections on terror is Hannah Arendt's The Origins of Totalitarianism (New
York, 1951).
} 
power and inequality on a world scale remain the key for understanding world history. ${ }^{41}$

Both narratives claim current relevance, and they are often intertwined-with good reason. Historians cannot simply divide European from Asian and African genocides: the massive loss of life in the Chinese Communist consolidation of power, in imposing the Vietnamese revolution, and in the Pol Pot episode in Cambodia emanated from party leaders who had absorbed revolutionary Marxisrn from the West. ${ }^{42}$ Recent interpretations of the Holocaust stress its continuity with genocidal practices in the colonies (for instance, the suppression of the Herero in Africa) as much as with specific anti-Semitism. They point to the power of Social Darwinist concepts of racial extinction in both arenas. Students of American slavery or South African apartheid have found the experience of German and European Jews extremely relevant for insisting on the moral horror of the experiences they are committed to studying. Conversely, analysts of what seems like murderous ethnic or "communal" violence that despairing observers attribute to collective psychopathology (or sometimes "ancient hatreds") can attribute the outbreaks to the legacies of division that former colonial rulers encouraged and perpetuated. In short, the causation for these varying stories of moral atrocity is often intertwined. Indeed, the most powerful and original, if sometimes misleading, analysis, Hannah Arendt's Origins of Totalitarianism, treated this innovation of the twentieth century as a single phenomenon and imperialism as one of its preparatory stages. Exponents of the Holocaust narrative claim that it teaches general lessons about genocide and ethnic cleansing, citing Bosnia and sometimes Rwanda (also claimed as instructive for the imperialist narrative), but they remain vague as to what underlying reasons these should be attributed. Not surprising, since the publicists of the Holocaust or Communist atrocities also have a stake in claiming the unique awfulness of their respective atrocities. In fact, the first narrative (now considering the history of Nazi and Soviet terror as one) tends to maintain its power less because of current horrors than by the attention it pays to judicial trials, negotiations over monetary reparation, and debates about suitable historical commemoration. For all the claims of relevance, the first narrative, therefore, has achieved a certain closure. ${ }^{43}$

4) For an introduction to what is now a huge literature (which this author makes no claim to have mastered), which seeks agency among the colonized and indeed attributes much of the Europeans' self-conceptions of gender, citizenship, and historical achievements in general to the interactions with colonial subjects, see Dipesh Chakrabarty, "Postcoloniality and the Artifice of History: Who Speaks for Indian Pasts?" Representations 37 (1992): 1-26; Gyan Prakash, "Subaltern Studies as Postcolonial Criticism," AHR 99 (December 1994): 1475-90; Ranajit Guha and Gayatri Chakravorty Spivak, eds., Selected Subaltern Studies (New York, 1988); Partha Chatterjee, The Nation and Its Fragments: Colonial and Postcolonial Histories (Princeton, N.J., 1993); for emphases on gender, Julia Clancy Smith and Frances Gouda, eds., Domesticating the Empire: Race, Gender, and Family Life in French and Dutch Colonialism (Charlottesville, Va., 1998); Frederick Cooper and Ann Laura Stoler, eds., Tensions of Empire: Colonial Cultures in a Bourgeois World (Berkeley, Calif., 1997); and from a different disciplinary vantage, James C. Scott, Weapons of the Weak: Everyday Forms of Peasant Resistance (New Haven, Conn., 1985).

42 For an instructive discussion of the limits (and possibilities) of comparison, with citation of the relevant literature, see Patrick Raszelenberg, "The Khmers Rouges and the Final Solution," History and Memory 11 (Fall-Winter 1999): 62-93.

4.3 No effort will be made here to cite the massive interpretive literature on the Holocaust and comparative genocide. For the range of interpretations and sources, see Omer Bartov, "Defining Enemies, Making Victims: Germans, Jews, and the Holocaust," AHR 103 (June 1998): 771-816. For a 
In contrast, the second narrative has become increasingly actual or contemporary for many intellectuals in Europe and North America, though not for those convinced that Nazism or Stalinism and Maoism remain the culminating evils of the century. "It is ironic," Edward Said has argued,

that descriptions of the new form of imperialism have regularly employed idioms of gigantism and apocalypse that could not have as easily been applied to the classical empires during their heyday. Some of these descriptions have an extraordinarily dispiriting inevitability, a kind of galloping, engulfing, impersonal, and deterministic quality. Accumulation on a world scale; the world capitalist system; the development of underdevelopment; imperialism and dependency, or the structure of dependence; poverty and imperialism: the repertory is well-known in economics, political science, history, and sociology, and it has been identified less with the New World Order than with members of a controversial Left school of thought. 44

One obvious reason is that the imperialist narrative always had a central economic component, and the story of economic exploitation has continuing appeal. Those who insist that irrevocable differences of culture (by which they sometimes mean worthiness) explain economic outcomes will remain doubtful; nevertheless, for the last thirty years, different versions of the story that attributes Third World poverty to First World wealth have found a receptive audience, whether the "dependency" theory of the 1960s, the analyses of the United Nations Conference on Trade and Development and the 1980 Brandt report, North-South: A Program for Survival, or the critiques of International Monetary Fund policies in the recent Asian crises. The growing inequality of incomes within the United States during the recent decade of prosperity also prompts a receptivity for the second narrative, which focuses, after all, on the continuing discrepancy of life chances and rewards. The global segmentation of the world economy finds itself replicated in the spatial segmentation and ethnically based class structure of the modern metropolis. ${ }^{45}$ Add to the unease about inequality the influential voice of postcolonial theory within the university, which essentially has refurbished the imperialist story and made it fundamental for literature and criticism, along with related tropes of diasporas, border crossing, and migration-and one finds a renewed attention to the second narrative. "Where once the transmission of national traditions was the major theme of a world literature, perhaps we can now suggest that transnational histories of migrants, the colonized, or political refugees-these border and frontier conditions-may be the terrains of world literature." 46 And of world history too, but by supplementing, not displacing, the earlier terrains.

Which brings us back, in fact, to the periodization proposed above for social and political development. For is it not the very decomposition of traditional territoriality, of the presumed identity between decision space and identity space, and the very newness of post-territoriality in the last three decades that help renew the

recent survey of debates over commemoration in Germany, Peter Reichel, Politik mit der Erinnerung: Gedächtnisorte im Streit um die nationalsozialistische Vergangenheit, rev. edn. (Frankfurt am Main,
1999).

${ }^{44}$ Edward W. Said, Culture and Imperialism (New York, 1993), 283.

${ }^{45}$ Sassen, Global City, 245-319.

4t Homi K. Bhabha, The Location of Culture (London, 1994), 12. 
persuasiveness of the imperialist narrative? Caught up since the 1980s in an age of so-called globalization, or at least a second wind for market regulation of political economy (and a second wind, too, for U.S. superpower status after the faltering of the 1970s), the non-celebrants have insisted on the continuing relevance of economic inequality, labor migration and exploitation, the power of Western capital, and the division of hegemonic and subaltern classes.

Of course, the Holocaust and the Gulag remain powerful stories; we remain in the grip of their memories, which are still compelling. But they grip us precisely as memory. They have left historians and witnesses to retell familiar events in the trials of octagenarians now hard to imagine as callous officials and killers. They have bequeathed controversies over memorials and museums and historical accounts, a sophisticated reflection on "representation" (see the journal History and Memory as well as Representations), and the renewed, now urgent, claims for payments to victims-all of which are fiercely debated in a context of universal agreement that the events at their origin were a non plus ultra of brutality and evil. The fact that these issues have not faded in intensity, despite predictions that after half a century or more they must, helps to keep vivid the obsessive violence of the era when territorial control seemed the basis of world politics. And they remain as a prick to conscience in the episodes of ethnic cleansing that we intervene to inhibit so belatedly. But as a narrative of annihilation, the Holocaust is hard to apply to political challenges that seem to fall short of its horror.

No READER SHOULD BELIEVE THAT THE WANING OF TERRITORIALITY does not have profound political implications. Insofar as territory loses its role as a resource for political action, it reappears as a sort of elegiac enclave, transmuted from the site of policy contention to a landscape of memory. It is not coincidental that the intense interest in historical museums, sites of mourning, evocations of old battlefields or even of neighborhoods becomes intense at a moment when territoriality weakens as an option for politics. The apparent thirst for history as a public pursuit, as a source for successful movies, or as a staple for television presentations may come at a price-an attitude of passive surrender to history itself that Lutz Niethammer and others have termed "Posthistoire." ${ }_{7}$ With its "moving chords of memory," the locations of history tug at our heartstrings and allow us to debate endlessly over museums and memorials while accepting - whether realistically or from exhaustion, depending on the perspective of the observer-the continuing limits on publicpolicy responses to social problems.

The waning of territoriality means further that culture or civilization replaces space as the stake of international or community conflict. Whether by virtue of direct migration or competitive economic exchange, the well-off and educated residents of the West are fated to live in proximity to, and without territorial protection from, peoples of other traditions. Even if far away and not just across town, the collapse of spatiality makes them virtual neighbors. Without the protection of territory, are we not destined, then, so it is suggested, for a continuing

47 Lutz Niethammer, Posthistoire: Ist die Geschichte zu Ende? (Reinbek bei Hamburg, 1989). 
conflict of civilizations and cultures? Does not culture become the explanatory trope for all group frictions-and one that suggests they can never really be transcended? ? $^{4}$

Finally, the moral narratives for the twentieth century arrive with profound implications for current politics. It is not the task of the historian to suggest which choices should be made but to illuminate how different historical interpretations suggest differing current options-that is, to point out the political freight respective interpretations may bear. Is it just coincidence that many of those for whom the combined narrative of Holocaust and Gulag, Nazism and Communism, retains priority have emerged with a profound distrust of transformative politics? They have drawn the lesson from ideological murder that all political projects are suspect and that modernity is best entrusted to the market or the institutions of civil society with a minimum of state intervention. Whereas the conclusion drawn by those who give priority to the imperialist or neo-colonial narrative is precisely the opposite: they argue that society must deploy political regulation to control international capital and unbridled market forces, just as local economic misfortunes must continue to be mitigated by the welfare state.

Does the twentieth-century history I have sketched offer any guidance in this confrontation? It does suggest, I think, that those who aspire to use political resources to mitigate market inequalities will have to do so on a post-territorial basis or, at the least, on different scales of territorial space and with a different combination of local and supranational resources than they did before the 1970s. The capacity of traditional territorial units, nation-states, conceived as they were in the nineteenth century, to keep their peoples from being buffeted by globalization has drastically diminished, and it seems fruitless to aspire to revive the Keynesian reformism of the 1930s and 1940s and even the 1960s successfully. Social democracy, as conceived in the interwar and early postwar period, applied in one country in an era of highly mobile capital means stagnation. Perhaps the emerging supranational agglomerations, such as the European Union, will provide a viable territorial base for political intervention, often by helping the success of local developmental strategies, whether in Ireland, Flanders, or Bavaria. The experiment is under way. But those efforts that promise economic success aim at development, and development tends ultimately to draw in non-local inhabitants. Consequently, reaffirming a territorial strategy to control economic destiny may involve diminishing cultural cohesion. Carinthia or Catalonia might choose to be rich or ethnically homogenous, but not both. In any case, to abjure political intervention is also risky. If advocates of liberalization will not heed the unequal costs entailed by the transition, at least, to a global economic order, they will not confront just disquieted environmentalists and labor leaders concerned with exploitation of workers at home and abroad. They will also encounter the populist advocates of closing frontiers, controlling migration, and ultimately bashing dissent. Look at the electoral returns in Austria or even Switzerland. A populism built on the longing for

\footnotetext{
${ }^{48}$ Contemporary diagnoses have oscillated between such neo-Spenglerian analyses as Samuel $\mathrm{P}$. Huntington, The Clash of Civilizations and the Remaking of World Order (New York, 1996), and the optimistic scenarios of market-democracy convergence: Francis Fukuyama, The End of History and the
Last Man (New York, 1992).
} 
a politically effective identity space and the control of frontiers may be archaic, but not everyone will draw the conclusion that it is hateful. History can recur as catastrophe as well as farce. Already two decades into what is really the new century, we cannot predict the surprises it undoubtedly has in store.

Charles S. Maier is a member of the History Department and Krupp Foundation Professor of European Studies and Director of the Minda de Gunzburg Center for European Studies at Harvard University. His most recent book was Dissolution: The Crisis of Communisn and the End of East Germany (1997). With William Kirby, he is currently collaborating on a world history of the twentieth century (despite intellectual reservations about periodization) and preparing a book-length study based on concepts proposed in this essay. 